\title{
Metode Pembelajaran Discovery untuk Meningkatkan Hasil Belajar Bahasa Indonesia dalam Menyimpulkan Isi Puisi Siswa Kelas VII G MTsN 9 Ngawi Tahun Pelajaran 2017/2018
}

\author{
Sulastri \\ MTsN 9 Ngawi
}

\begin{abstract}
Abstrak
Penelitian ini bertujuan untuk (1) Mengetahui hasil belajar siswa setelah diterapkannya metode discovery dalam belajar Bahasa Indonesia pada siswa kelas VII-G MTsN 9 Ngawi tahun pelajaran 2017/2018; dan (2) Mengetahui penerapan metode discovery dalam belajar Bahasa Indonesia pada siswa kelas VII-G MTsN 9 Ngawi semester Genap Tahun Pelajaran 2017/2018.Penelitian ini merupakan penelitian tindakan kelas (action research) karena penelitian dilakukan untuk memecahkan masalah pembelajaran di kelas. Subjek penelitian adalah siswa kelas VII-G MTsN 9 Ngawi di Kabupetan Ngawi. Prosedur penelitian dengan melakukan perencanaan, tindakan, observasi, dan refleksi.Hasil penelitian ini menunjukkan bahwa; (1) tingkat keberhasilan siswa pada siklus I adalah $28 \%+4 \%=32 \%$. Siswa yang mampu menyimpulkan isi puisi rakyat sebanyak 8 siswa dan yang belum bisa menyimpulkan isi puisi sebanyak 17 siswa. Sedangkan, tingkat keberhasilan siswa pada siklus II adalah $56 \%+24 \%=80 \%$. Siswa yang mampu menyimpulkan isi puisi rakyat sebanyak 20 siswa. (2) Model pembelajaran discovery memiliki dampak positif dalam meningkatkan hasil belajar siswa yang ditandai dengan peningkatan kuktasan belajar siswa dalam setiap siklus, pada siklus I $(32 \%)$ dan siklus ke II $(80 \%)$. Penerapan cara belajar menyimpulkan isi puisi rakyat model pembelajaran discoveryberpengaruh dalam menigkatkan motivasi belajar siswa yang ditunjukkan dengan keluwesan berbicara siswa dalam menyimpulkan isi puisi rakyat.
\end{abstract}

Kata kunci :Metode pembelajaran discovery, hasil belajar, puisi

\section{PENDAHULUAN}

Pendidikan merupakan salah satu kunci bagi seseorang dalam mencapai tujuan kehidupan yang sukses. Pendidikan bukan sekadar proses membekali siswa dengan ilmu pengetahuan tetapi juga membekali siswa dengan budi pekerti yang luhur. Seseorang yang mempunyai intelektualitas tinggi namun tidak didukung dengan moralitas yang luhur akan membawa orang tersebut menjadi pribadi yang tidak mengaplikasikan nilai-nilai kemanusiaan dalam hidupnya. Oleh karenanya, antara pendidikan dan moralitas diperlukan kesinambungan dan hubungan yang sinergis agar tercapailah sebuah kehidupan yang harmonis.
Pembelajaran Bahasa Indonesia erat kaitannya dengan guru Bahasa Indoensia yang setiap harinya mengajarkan pelajaran Bahasa Indonesia. Guru Bahasa Indonesia merupakan orang yang bertanggung jawab pada perkembangan ilmu bahasa Indonesia dan sebagai penyelenggara pendidikan di Indonesia. Penyelenggaraan pendidikan bertujuan untuk mendidik siswa menjadi manusia yang bertaqwa kepada Tuhan Yang Maha Esa, berbudi luhur, cerdas, kreatif, dan terampil(Permana, 2015).

Pengajaran Bahasa Indonesia ada banyak yang perlu diperhatikan, misalnya saja materi mengarang. Menurut Tarigan (1986:1), keterampilan berbahasa Indonesia meliputi empat jenis keterampilan yaitu 
menyimak, berbicara, membaca, dan menulis.Materi ini mungkin dianggap sepele oleh beberapa kalangan. Materi menggarang mencangkup unsur kebahasaan untuk mengetahui ketrampilan siswa dalam penggunaan kosakata secara verbal maupun tulisan. Dalam hal ini guru dihadapkan pada masalah yang dilematis. Guru bahasa indonesia harus dapat menyelesaikan target kurikulum yang harus dicapai dalam kurun waktu yang telah ditentukan. Sedangkan, pembelajaran mengarang membutuhkan waktu yang lama karena diperlukan latihanlatihan untuk siswa belajar mengarang. Sekolah pada umumnya mengabaikan pelajaran mengarang, sehingga siswa kurang termotivasi untuk belajar mengarang.

Perwujudan pembelajaran yang bermakna salah satunya ditinjau dari keterampilan siswa(Permana, 2016). Menyimpulkan sebuah isi puisi rakyat merupakan sebuah ketrampilan berbahasa yang cukup rumit. Karena melibatkan tidak hanya bermodal pandai mengarang tetapi juga harus mempunyai tata bahasa diantaranya kemampuan menyusun pikiran dan perasaan dengan menggunakan katakata dalam bentuk kalimat sesuai kaidah tata bahasa indonesia. Meyimpulkan sebuah karangan perlu dikembangkan dalam dunia pendidikan karena dapat melatih siswa untuk berpikir kritis dalam menanggapi sesuatu yang terjadi disekitarnya. Berdasarkan masalah yang muncul, maka penelitian ini dirancang dengan Penelitian Tindakan Kelas sebagai upaya meningkatkan hasil belajar dalam menyimpulkan isi puisi rakyat siswa kelas VII-G MTsN 9 Ngawi menggunakan metode discovery.

Penelitian ini bertujuan untuk (1) Mengetahui hasil belajar siswa setelah diterapkannya metode discovery dalam belajar Bahasa Indonesia pada siswa kelas VII-G MTsN 9 Ngawi tahun pelajaran
2017/2018; dan (2) Mengetahui penerapan metode discovery dalam belajar Bahasa Indonesia pada siswa kelas VII-G MTsN 9 Ngawi semester Genap Tahun Pelajaran 2017/2018.Penelitian ini merupakan penelitian tindakan kelas (action research) karena penelitian dilakukan untuk memecahkan masalah pembelajaran di kelas.

Langkah selanjutnya yaitu memodifikasi dan menyesuaikan dengan kebutuhan di SD, hal itu selain karena memiliki kelemahan, juga untuk melakukan inovasi metode pembelajaran yang efektif yang didasarkan dari bawah (an inquiry of practice from within). Hasil refleksi bersama (team work reflective inquiry) memutuskan bahwa perlu mengadakan inovasi model, yakni yang menekankan kepada; (1) kebutuhan murid yang memerlukan interaksi pembelajaran yang akademis emosional, (2) pemerintah melalui Depdiknas menekankan peningkatan prestasi belajar murid, dan (3) guru SD dan dosen belajar membiasakan melakukan inovasi melalui modifikasi model pembelajaran dengan PTK(Yuliantini, 2017).

\section{METODE PENELITIAN}

Metode Penelitian yang digunakan yaitu penelitian tindakan kelas (PTK) yang berkolaboratif (collaborative classroom action research) (Martin, 2008) PTK ini menggunakan model guru sebagai peneliti (teacher as researcher) (Ryan et al., 2017). Model ini relevan bagi guru dan dosen dan memiliki keunggulan, sebab efektif dapat memperbaiki kualitas pembelajaran yang dilakukannya. Pelaksanaan penelitian ini terdiri atas tiga langkah yaitu : (1) diagnostik (perumusan masalah dan hipotesis tindakan), (2) terapetik (perbaikan yang terdiri atas beberapa siklus: perencanaan, pelaksanaan, pengamatan refleksi); dan (3) pasca terapetik 
(pemantapan dan pembuatan laporan) (Baker, 2001 : 3).Menurut Kemmis dan Taggart (1988: 14) dalam Arikunto (2002: 83), menyatakan bahwa model penelitian tindakan adalah berbetuk spiral. Tahapan penelitian tindakan pada suatu siklus meliputi perencanaan atau pelaksanaan observasi dan refleksi. Siklus ini berlanjut dan akan berhenti jika sesuai dengan kebutuhan dan dirasa sudah cukup.

Tempat penelitian adalah tempat yang digunakan dalam melakukan penelitian untuk memperoleh data yang diinginkan. Penelitian ini bertempat di MTsN 9 Ngawi Tahun Pelajaran 2017/2018. Subjek peneitian pada penelitian ini merupakan siswa kelas VIII A MTsN 9 Ngawi tahun pelajaran 2017/2018. Dan waktu berlangsungnya penelitian atau saat penelitian ini dilangsungkan pada bulan Januari sampai Februari tahun pelajaran 2017/2018.

\section{HASIL DAN PEMBAHASAN}

\section{Siklus I}

$$
\text { Pada tahap ini peneliti }
$$
mempersiapkan perangkat pembelajaran yang terdiri dari rencana pembelajaran dan tugas meyimpulkan isi puisi dalam bentuk lisan. Selain itu, peneliti juga mempersiapkan lembar observasi.Peneliti bertindak sebagai guru mata pelajaran bahasa Indonesia. Proses belajar mengajar mengacu pada rencana pelajaran yang telah dipersiapkan.

Tabel 1. Pengamatan Pengamatan Siklus I.

\begin{tabular}{|l|c|c|}
\hline Kategori & Frekuensi & Presentasi \\
\hline Benar semua & 7 & $28 \%$ \\
\hline Benar sebagian & 1 & $4 \%$ \\
\hline Salah semua & 10 & $40 \%$ \\
\hline $\begin{array}{l}\text { Tanpa } \\
\text { percakapan }\end{array}$ & 7 & $28 \%$ \\
\hline
\end{tabular}

Pada akhir kegiatan pembelajaran siklus I siswa diberi tugas untuk menyimpulkan isi puisi rakyat. Dari tugas tersebut diperoleh hasil keberhasilan siswa pada siklus I adalah $28 \%+4 \%=32 \%$. Siswa yang mampu menyimpulkan isi puisi rakyat sebanyak 8 siswa dan yang belum bisa menyimpulkan isi puisi sebanyak 17 siswa. Hal ini menunjukkan siswa kurang memperhatian dan kurang memahami apa yang disampaikan guru. Hasil pengamatan masih kurang memuaskan karena siswa masih kesulitan membentuk kata-kata. Hasil tersebut menunjukkan siklus I secara umum siswa belum tuntas belajar.

\section{Siklus II}

Pada siklus II ini peneliti melakukan hal yang sama pada siklus I, yakni memberikan tugas pada siswa untuk menyimpulkan isi puisi rakyat.

Tabel 2. Pengamatan Siklus II.

\begin{tabular}{|l|c|c|}
\hline Kategori & Frekuensi & Presentasi \\
\hline Benar semua & 14 & $56 \%$ \\
\hline Benar sebagian & 6 & $24 \%$ \\
\hline Salah semua & 4 & $16 \%$ \\
\hline $\begin{array}{l}\text { Tanpa } \\
\text { percakapan }\end{array}$ & 1 & $4 \%$ \\
\hline
\end{tabular}

Hasil dari siklus II ini menunjukkan hasil $56 \%+24 \%=80 \%$. Siswa yang mampu menyimpulkan isi puisi rakyat sebanyak 20 siswa. Siswa yang belum bisa menyimpulkan isi puisi sebanyak 5 siswa. Hasil ini menunjukkan bahwa pada siklus II ketuntasan belajar pada umumnya telah tercapai. Terlihat ada pengingkatan belajar pada siklus II dipengaruhi oleh peningkatan kemampuan guru dalam menerapkan metode belajar discovery pada kegiatan pembelajaran sehingga siswa mudah untuk memahami materi yang telah diberikan.

\section{SIMPULAN}

Kemampuan menyimpulkan isi puisi rakyat dapat ditingkatkan dengan model pembelajaran discovery. Kegiatan 
mengarang dan menyimpulkan isi puisi rakyat membutuhkan latihan yang harus dilakukan secara berulang-ulang. Dari hasil kegiatan pembelajaran yang dilakukan selama dua siklus, dapat disipulkan sebagai berikut. Model pembelajaran discovery memiliki dampak positif dalam meningkatkan hasil belajar siswa yang ditandai dengan peningkatan kuktasan belajar siswa dalam setiap siklus, pada siklus I (32\%) dan siklus ke II (80\%).Penerapan cara belajar siswa menyimpulkan isi puisi rakyat model pembelajaran discovery berpengaruh dalam menigkatkan motivasi belajar siswa yang ditunjukkan dengan keluwesan berbicara siswa dalam menyimpulkan isi puisi rakyat.

\section{SARAN}

Untuk melaksanakan model
pembelajaran discovery memerlukan persiapan yang cukup sehingga guru mampu menentukan topik puisi yang akan disimpulkan dan bisa diterapkan dalam model pembelajaran discovery sehingga memperoleh hasil yang maksimal. Perlu adanya penelitian lebih lanjut karena hasil penelitian ini hanya dilakukan di MTsN 9 Ngawi.Untuk penelitian yang serupa hendaknya dilakukan perbaikan-perbaikan agar diperoleh hasil yang lebih baik.

\section{DAFTAR PUSTAKA}

Arikunto, Suharsimi. 2002. Prosedur Penelitian Suatu Pendekatan Praktek. Jakarta: PT Rineksa Cipta.

Baker, G.. (2001). Action Research In Elementary Education : The Strrategic Pratice.
http://www.ed.gov/databases/ERICDig est/Ed401047. html. (6 januari 2017).

Kemmis, S. and McTaggart, R. (eds) (1988)

The Action Research Planner. (Third

Edition) Waurn Ponds: Deakin

University Press.

Martin, L. A. (2008). Elementary and

Secondary Teacher Education

Students' Perspectives on Citizenship.

Action in Teacher Education, 30(3),

54-63.

https://doi.org/10.1080/01626620.2008. 10463502

Permana, E. P. (2015). Pengembangan

Media Pembejaran Boneka Kaus Kaki

Untuk Meningkatkan Keterampilan

Berbicara Siswa Kelas II Sekolah

Dasar. Profesi Pendidikan Dasar, 2(2), 133-140.

https://doi.org/10.23917/ppd.v2i2.1648

Permana, E. P. (2016). Penerapan Metode

Pembelajaran Kooperatif Numbered

Heads Together (NHT) Untuk

Meningkatkan Hasil Belajar Dan

Berpikir Kritis Siswa Pada Mata

Pelajaran IPS SD. Jurnal Pendidikan

Dasar Nusantara, 1(2), 49-58.1(2).

https://doi:10.29407/jpdn.v1i2.210

Ryan, M., Taylor, M., Barone, A., Della

Pesca, L., Durgana, S., Ostrowski, K.,

... Pikaard, K. (2017). Teacher as

Researcher, Teacher as Scholar, and

Teacher as Leader. The New Educator, 13(2), 102-116.

https://doi.org/10.1080/1547688X.2016 .1144120

Yuliantini, N. (2017). Penerapan Model

Pembelajaran Interaktif Akademis

Emosional Untuk Peningkatan Prestasi

Belajar (PTK pada mata pelajaran

Bahasa Indonesia di kelas V SDN 86

Kota Bengkulu). PINUS: Jurnal

Penelitian Inovasi Pembelajaran, 3(1), 49-53.

https://doi.org/10.29407/pn.v3i1.913 